Scientific Journal Warsaw University of Life Sciences - SGGW

Problems of World Agriculture volume 17 (XXXII), number 4, 2017: 111-119

DOI: $10.22630 /$ PRS.2017.17.4.87

Silvia Jacková $^{1}$, Zuzana Kapsdorferová ${ }^{2}$, Ludmila Dobošová ${ }^{3}$, Mária Kadlečíková ${ }^{4}$

Slovak University of Agriculture in Nitra

\title{
Food Security and Self-Sufficiency in Europe
}

\begin{abstract}
The submitted scientific paper deals with food security and self-sufficiency in Europe in EU-15 and EU-13 countries. The objective of this paper was to evaluate upon the basis of the Global Food Security Index, the overall food security situation in the European Union states. The countries are divided into two groups. The first is composed of fourteen selected states from the EU -15 and the second group is six selected states from the EU-13. In addition to the Food Security Index, the Food Affordability, Food Availability, and the Food Quality and Safety Indexes were also analyzed. The research data were obtained from the authors" own research based on the Global Food Security Index Report, and from FAO.
\end{abstract}

Keywords: food security, food affordability, food availability, healthy diet, quality, Europe

JEL Classification: I15, O13

\section{Introduction}

Hunger and inadequate food supply are still affecting a large part of the world's population with serious consequences for health and well-being, especially in children. Undernutrition and malnutrition in childhood interfere with physical and mental development, thus compromising whole lives (United Nation System). About 793 million people are undernourished globally, which over the last decade is lower by about 167 million, and compared with the years 1990-1992 is lower by 216 million. These declines are more pronounced in developing regions, despite significant population growth. In recent years, progress has been hindered by slower and less inclusive economic growth, as well as by political instability in some developing regions, such as Central Africa and Western Asia (FAO, 2015). This is a challenging factor since food security is an important component of the process of economic development (Fogel, 2004). Over the last few decades, improvements in food security have come from increases in agricultural productivity as well as from reduction in extreme poverty (Godfray et al., 2010).

Undernourishment means that a person is not able to acquire enough food to meet the daily minimum dietary energy requirements, over a period of one year. FAO defines hunger as being synonymous with chronic undernourishment. According to the FAO Food Summit held in 1996, food security is a situation that exists when all people, at all times, have

\footnotetext{
${ }^{1}$ Ing., Department of Management, Faculty of Economics and Management, Slovak University of Agriculture in Nitra, Tr. Andreja Hlinku 2, 94976 Nitra, Slovakia, e-mail: silvia.jackova39@gmail.com

${ }^{2}$ doc. Ing., PhD., Department of Management, Faculty of Economics and Management, Slovak University of Agriculture in Nitra, Tr. Andreja Hlinku 2, 94976 Nitra, Slovakia, e-mail: zuzana.kapsdorferova@uniag.sk

${ }^{3}$ Ing., Department of Economics, Faculty of Economics and Management, Slovak University of Agriculture in Nitra, Tr. Andreja Hlinku 2, 94976 Nitra, Slovakia, e-mail: DobosovaL@gmail.com

${ }^{4}$ Dr. h.c. prof. h.c. doc. Ing., CSc., Department of Management, Faculty of Economics and Management, Slovak University of Agriculture in Nitra, Tr. Andreja Hlinku 2, 94976 Nitra, Slovakia, e-mail: maria.kadlecikova@uniag.sk
} 
physical, social and economic access to sufficient, safe and nutritious food that meets their dietary needs and food preferences for an active and healthy life (FAO, 2002). Thus, under food security, no individual faces hunger or starvation. Alternatively, food insecurity arises when some individuals face limited or uncertain access to nutritionally adequate and safe food. Situations of undernutrition are pervasive (Chavas, 2017). Family food security is the application of this concept to the family level, with individuals within households as the focus of concern.

Measurement is typically indirect and based on food balance sheets and national income distribution and consumer expenditure data. Linking hunger and sub-nutrition with inadequate food intake allows the measurement of food insecurity in terms of the availability and apparent consumption of staple foods or energy intake (FAO, 2002)

Undernourishment or chronic hunger is the inability of persons to consume enough food sufficient to meet dietary energy requirements. Malnutrition, in all its forms, is a major impediment to development. Malnutrition occurs when a person's diet contains too few or too many nutrients. Worldwide, annually 161 million children are stunted due to chronic malnutrition, 99 million children are underweight and 51 million children die due to acute malnutrition. The consequences of malnutrition range from increased risk of death, increased prevalence of diet-related non-communicable diseases and serious chronic health conditions (FAO, 2014).

According to Kadlečíková (2011) the same factors that are continuously causing the food crisis in less developed states still play an important role: agricultural productivity is low, the population growth rate is still high in many of the most food insecure countries; limited water availability and land tenure are also significant problems; in a world with changing climate, the frequency of floods and droughts is above long-term averages; another complication is linked to price volatility and to changing population patterns. Investments in agricultural research and development are much lower than what was recommended by experts during world food summits, and if the investments are realized then usually they are not directed toward the most important crops for the poor, but rather they support the development of biofuels, and land is used for energy crops.

FAO (2017a) Report identifies 15 trends affecting the world's food systems:

- A rapidly increasing world population marked by growth "hot spots," urbanization, and aging;

- Diverse trends in economic growth, family incomes, agricultural investment, and economic inequality;

- Greatly increased competition for natural resources;

- Climate change;

- Plateauing agricultural productivity;

- Transboundary diseases;

- Increased conflicts, crises and natural disasters;

- Persistent poverty, inequality and food insecurity;

- Dietary transitions affecting nutrition and health;

- Structural changes in economic systems and employment implications;

- Increased migration;

- Changing food systems and resulting impacts on farmers' livelihoods;

- Persisting food losses and waste; 
- New international governance mechanisms for responding to food and nutrition security issues;

- Changes in international financing for development.

Priefer (2016) asserts that an important tool to ensure and maintain food security and safety is to reduce food waste.

The situation in the EU states is significantly more optimistic in comparison with the African, Asian and Latin American continents (including Caribbean countries). The purpose of this paper is to evaluate the food security situation in the European Union states divided on the two groups. In the first group the fourteen selected states from the EU-15 are evaluated and in the second group the six selected member states from EU-13 are evaluated, with intention to highlight the strengths and weaknesses of both groups.

\section{Data and Methods}

Using this definition adapted from the 1996 World Food Summit, the Global Food Security Index considers the core issues of affordability, availability, and quality across a set of 113 countries. The index is a dynamic quantitative and qualitative scoring model, constructed from 28 unique indicators, that measures these drivers of food security across both developing and developed countries. The overall goal of this study is to assess which countries are the most and the least vulnerable to food insecurity through the categories of Affordability, Availability, and Quality and Safety (Global Food Security Index Report). Affordability measures the ability of consumers to purchase food, their vulnerability to price shocks and the presence of programs and policies to support customers when shocks occur. Availability measures the sufficiency of the national food supply, the risk of supply disruption, national capacity to disseminate food and research efforts to expand agricultural output. Quality and Safety measures the variety and nutritional quality of average diets, as well as the safety of food.

The downloaded data are from the Report on Food Security Index and from FAO. The objective of this paper is to point out the food security and sufficiency of EU states. Data is divided into two groups- EU-15 and EU-13. The EU-15 states consist of Austria, Belgium, Denmark, France, Finland, Germany, Greece, Ireland, Italy, Luxemburg, Netherlands, Portugal, Spain, Sweden and United Kingdom. Into the EU-13 group are Bulgaria, Croatia, Cyprus, Czech Republic, Estonia, Hungary, Latvia, Lithuania, Malta, Poland, Romania, Slovak Republic and Slovenia. For the purpose of this paper, 14 states from the EU-15 and 6 states from EU-13 have been selected, which are monitored by the Global Food Security Index.

\section{Results}

\section{Challenges of Agriculture and Food Production}

The current trends and challenges are reflected in 17 sustainable development goals for the next 15 years with an aim to balance economic, environmental, and social issues. Agriculture is focused on hunger and malnutrition and closely linked to other sustainable development goals such as: the end of poverty in all its forms everywhere; $70 \%$ of rural 
population is poor, gender equality is a great challenge; there is insufficient clean water and sanitation; it is important to use affordable and clean energy; rural populations need to have decent work and to ensure economic growth, responsible production and consumption; climate actions have to be taken into consideration and life should be economically and socially attractive. The sustainable development goals are linked to FAO Strategic Objectives: eliminate hunger, food insecurity and malnutrition; ensure productive and sustainable agriculture, forestry and fisheries; reduce rural poverty; create inclusive and efficient agricultural and food systems; and increase the resilience of livelihoods against disasters.

A big challenge for agriculture is, according to FAO (2017b), the eradication of extreme poverty, and ensuring that vulnerable people who escape poverty do not again fall back into it. This requires actions to reduce inequalities. Actually, it is about addressing inequalities both between and within countries, in levels of income, in opportunities, as well as in the ownership of assets, including land. Pro-poor growth strategies, which ensure that the weakest people will participate in the benefits of market integration and investments in agriculture, would improve their incomes and investment opportunities in rural areas and address the root causes of migration.

Social protection combined with pro-poor growth will help to meet the challenge of ending hunger and addressing the triple burden of malnutrition through healthier diets. Permanently eliminating hunger, malnutrition and extreme poverty also requires building resilience to protracted crises, disasters and conflicts, and preventing conflicts by promoting inclusive and equitable global development.

A rethinking of food systems and governance is essential for meeting current and future challenges. Vertically coordinated, more organized food systems offer standardized food for urban areas and formal employment opportunities. But they need to be accompanied by responsible investments and concern for smallholder livelihoods, the environmental footprint of lengthening food supply chains, and impacts on biodiversity. These concerns need to be addressed by making food systems more efficient, inclusive and resilient.

One of the greatest challenges is achieving coherent, effective national and international governance, with clear development objectives and commitments to achieving them. The 2030 Agenda for Sustainable Development embodies such a vision - one that goes beyond the divide of 'developed' and 'developing' countries. Sustainable development is a universal challenge and the collective responsibility for all countries, requiring fundamental changes in the way that all societies produce and consume.

\section{Global Food Security Index}

The Global Food Security Index considers the core issues of affordability, availability, and quality across a set of 113 countries. The index is a dynamic quantitative and qualitative scoring model, constructed from 28 unique indicators, that measures the abovementioned drivers of food security across both developing and developed countries. The Global Food Security Index consists of four categories: Affordability, Availability, Quality and Safety and the Global ranking is a final score. 


\section{The Global Ranking}

The ranking of EU-15 countries in terms of Global Ranking, Affordability, Availability and Quality and Safety according to the Global Food Security Index, is shown in Table 1.

Table 1. The Global and EU ranking of the Fourteen Selected States from EU-15 according to the Global Food Security Index for Availability, Affordability, Quality and Safety in 2016

\begin{tabular}{|c|c|c|c|c|c|c|c|c|}
\hline Country & $\begin{array}{c}\text { Global Ranking } \\
\text { in EU } \\
\text { countries }\end{array}$ & $\begin{array}{l}\text { Global } \\
\text { Ranking in } \\
\text { world }\end{array}$ & $\begin{array}{l}\text { Affordability } \\
\text { in EU } \\
\text { countries }\end{array}$ & $\begin{array}{l}\text { Affordability } \\
\text { in world }\end{array}$ & $\begin{array}{l}\text { Availability in } \\
\text { EU countries }\end{array}$ & $\begin{array}{c}\text { Availability in } \\
\text { world }\end{array}$ & $\begin{array}{l}\text { Quality and } \\
\text { Safety in EU } \\
\text { countries }\end{array}$ & $\begin{array}{l}\text { Quality and } \\
\text { Safety in world }\end{array}$ \\
\hline Ireland & 1 & 2 & 1 & 7 & 1 & 2 & & 7 \\
\hline Netherlands & 2 & 4 & 4 & 10 & 5 & 7 & & 5 \\
\hline France & 3 & 6 & 10 & 19 & 3 & 4 & & 2 \\
\hline Germany & 3 & 6 & 3 & 9 & 2 & 3 & 13 & 20 \\
\hline United Kingdom & 4 & 8 & 5 & 11 & 4 & 5 & 14 & 22 \\
\hline Sweden & 5 & 10 & 7 & 14 & 6 & 12 & & 11 \\
\hline Denmark & 6 & 14 & 6 & 12 & 8 & 15 & & 14 \\
\hline Portugal & 6 & 14 & 13 & 29 & 7 & 13 & & 1 \\
\hline Austria & 7 & 16 & 2 & 8 & 9 & 17 & 12 & 17 \\
\hline Finland & 8 & 17 & 9 & 18 & 10 & 18 & & 6 \\
\hline Spain & 9 & 19 & 11 & 20 & 11 & 19 & & 4 \\
\hline Belgivm & 10 & 21 & 8 & 16 & 12 & 22 & 11 & 16 \\
\hline Italy & 11 & 22 & 12 & 22 & 13 & 25 & 10 & 15 \\
\hline Greece & 12 & 31 & 14 & 36 & 14 & 32 & & 3 \\
\hline
\end{tabular}

Source. Authors' own elaboration on the basis of the Global Food Security Index.

For EU-15, the best result in Global Ranking was reached by Ireland, which is ranked in second position in the world ranking and first in the EU-15 ranking. From the point of view of Global Ranking, the most serious situation is in Greece, which is on the 31st position and is in the last (fourteenth) place in the framework of EU-15 countries which are evaluated by the Global Food Security Index. Overall, the selected fourteen states from EU-15 are achieving very good results, but those ranked last are listed as Belgium, Italy and Greece. All of the twelve EU states are ranked in the first twenty countries around the world. This means that the Food security among the Western members of the EU is very high and makes them the strongest states in the world from the angle of food affordability, food availability and quality.

For EU-13 countries, the situation is less favorable. The best result is achieved by the Czech Republic with ranking on the 25th place in terms of Global Ranking worldwide. This situation is shown in Table 2. The least favorable position is occupied by Bulgaria. Its Global Ranking is on the $50^{\text {th }}$ place, while within six selected EU-13 states Bulgaria occupies the last position. Slovakia has the 40th position worldwide, according to the Global Ranking. From the V4 countries (Visegrad group) which are Slovakia, Czech Republic, Hungary and Poland, Slovakia has the most moderate results. However, the Slovak Republic has the potential for better results, if it manages to use its natural and 
human resources more effectively, as well as its comparative advantage. Nevertheless, to occupy the $40^{\text {th }}$ position worldwide means a good level of food security, but it is the responsibility of each state to enhance its own potential with aims to support world food security through the WFP food aid, EU, ODA and other institutional and NGO activities.

Table 2. The Global and EU ranking of the Six Selected States from EU-13 according of the Global Food Security Index on Availability, Affordability, Quality and Safety in 2016

\begin{tabular}{l|cccccccc}
\hline \multicolumn{1}{c|}{ Country } & $\begin{array}{c}\text { Global Ranking } \\
\text { in EU } \\
\text { countries }\end{array}$ & $\begin{array}{c}\text { Global } \\
\text { Ranking in } \\
\text { world }\end{array}$ & $\begin{array}{c}\text { Affordability } \\
\text { in EU } \\
\text { countries }\end{array}$ & $\begin{array}{c}\text { Affordability } \\
\text { in world }\end{array}$ & $\begin{array}{c}\text { Availability in } \\
\text { EU countries }\end{array}$ & $\begin{array}{c}\text { Availability in } \\
\text { world }\end{array}$ & $\begin{array}{c}\text { Quality and } \\
\text { Safety in EU } \\
\text { countries }\end{array}$ & $\begin{array}{c}\text { Quality and } \\
\text { Safety in world }\end{array}$ \\
\hline Czech Republic & 1 & 25 & 1 & 25 & 1 & 27 & 1 & 26 \\
Hungary & 3 & 34 & 2 & 30 & 4 & 47 & 4 & 33 \\
Poland & 2 & 29 & 2 & 30 & 2 & 29 & 2 & 30 \\
Slovak Republic & 4 & 40 & 3 & 33 & 3 & 45 & 5 & 45 \\
Romania & 5 & 42 & 5 & 42 & 5 & 48 & 3 & 31 \\
Bulgaria & 6 & 50 & 4 & 36 & 6 & 69 & 6 & 54 \\
\hline
\end{tabular}

Source: Authors' own elaboration on the basis of the Global Food Security Index.

From the perspective of overall food security, the EU-15 has a visibly better situation than the EU-13. However, in general we can declare that the EU is self-sufficient and is rated very well, because all EU states are listed among the top fifty from all 113 of the surveyed countries on the list of the Global Food Security Index.

\section{Food Affordability}

Affordability measures the ability of consumers to purchase food, their vulnerability to price shocks and the presence of programs and policies to support customers when shocks occur. Table 1 shows the situation in this indicator for the selected fourteen states of the EU-15. The best results are again achieved by Ireland which occupies 7 th position in the global ranking, while Germany is in 9th position. At the other end, the least favorable position is held by Greece at 36th, however, this can still be considered a very good result for the country, as well as for the rest of the states in the EU-15.

In the selected six states from the EU-13, the best position is found in the Czech Republic with regard to Food Affordability. It occupies $25^{\text {th }}$ position in the global ranking. Romania is listed last at $42^{\text {nd }}$. Slovakia achieved a very good position in this indicator, listed $33^{\text {rd }}$, which actually means the third best position in frame of EU-13 countries.

Concerning the Food Affordability indicator, all EU states which were included into the evaluation of their Global Food Security Indicator are listed up to $40^{\text {th }}$ position over the world. This result leads us to the statement that the food affordability in the EU states is achieving very satisfactory results. In addition to this, EU members have the highest food security level in the world.

\section{Food Availability}

Availability measures the sufficiency of the national food supply, the risk of supply disruption, national capacity to disseminate food and research efforts to expand 
agricultural output. Table 1 exhibits the Global Ranking in the Food Availability for fourteen selected EU-15 countries. The global second place belongs to Ireland, third is granted to Germany and number four to France. The last place from this group (32) is Greece.

Table 2 shows the ranking for six selected states of the EU-13 with regard to the Food Availability Indicator. The best results from this group of states, are found once more in the Czech Republic. Poland has a very similar evaluation as it is ranked $29^{\text {th }}$ in the global list, the Slovak Republic is listed as $45^{\text {th }}$ followed by Romania at $48^{\text {th }}$. Bulgaria occupies the $69^{\text {th }}$ place, which is weakest result from these states. In general, we can conclude that from the selected six states of the EU-13, the highest level of Food Security from the point of view of Food Availability is achieved in the Czech Republic, as well as in Poland. Somewhat more moderate results had been noted in Hungary and the Slovak Republic, and partially in Romania. From the perspective of Food Availability, the security situation is rather critical in Bulgaria. This country has difficulties with the smooth sufficiency of the national food supply and there exists the serious risk of food supply disruption.

Table 3. The Overall Score, Affordability, Availability, Quality and Safety of the Fourteen Selected States from EU-15 according to the Global Food Security Index in 2016

\begin{tabular}{l|cccc}
\hline \multicolumn{1}{c|}{ Country } & Overall score & Affordability & Availability & $\begin{array}{c}\text { Quality and } \\
\text { Safety }\end{array}$ \\
& & & & \\
\hline Austria & 79,3 & 81,9 & 75,6 & 82,8 \\
Belgium & 77,4 & 80,2 & 72,7 & 82,9 \\
Denmark & 80,0 & 81,3 & 77,7 & 83,4 \\
Finland & 78,9 & 79,8 & 75,4 & 86,0 \\
France & 82,5 & 79,7 & 82,7 & 88,7 \\
Germany & 82,5 & 81,7 & 83,8 & 81,3 \\
Greece & 71,5 & 69,6 & 67,8 & 86,3 \\
Ireland & 84,3 & 82,4 & 85,4 & 85,8 \\
Italy & 75,9 & 78,6 & 70,8 & 83,3 \\
Netherlands & 82,6 & 81,6 & 82,3 & 86,1 \\
Portugal & 80,0 & 76,2 & 79,9 & 89,7 \\
Spain & 77,7 & 78,9 & 73,6 & 86,2 \\
Sweden & 81,3 & 81,0 & 80,1 & 85,4 \\
United Kingdom & 81,9 & 81,5 & 82,6 & 81,0 \\
\hline
\end{tabular}

Source: Authors' own elaboration on the basis of the Global Food Security Index.

The Food Quality and Safety

In Food Quality and Safety, the ranking of the selected fourteen states of EU-15, is different from the above-demonstrated results (Table 1). The best food quality and safety is in Portugal. For this indicator the country has achieved significantly better results than in 
the case of previous indicators. Concerning food quality and safety, Greece is listed on the world in $5^{\text {th }}$ place, which is the $3^{\text {rd }}$ best place in EU-15 countries. Compared to previous indicators, where Greece was always rated as the country with the weakest results, for food quality and safety it has achieved the best results. Nevertheless, all fourteen selected states are listed among the 22 best-performing in the world with regard to food quality and safety.

From the selected six states of the EU-13, the first position in food quality and safety belongs again to the Czech Republic when we consider its world ranking at $26^{\text {th }}$. In this indicator the Czech Republic is followed by Poland, listed at $30^{\text {th }}$, Romania at $31^{\text {st }}$ position and Hungary ranked at $33^{\text {rd }}$ in the world. Surprisingly, Slovakia is on the $45^{\text {th }}$ position and from the selected six states of the EU-13 it is in the second-to-last position. With regard to food quality and safety it seems that Slovakia must improve the variety and nutritional quality of its average diet, as well as the safety of food. Similarly, the weakest performance with regard to food quality and safety was noted in Bulgaria; however, from the global point of view its position for this indicator is not so critical, as it was earlier mentioned, as their weakest result was achieved in the indicator of food availability (ranking at $69^{\text {th }}$ position).

According to the results shown in Table 3, the highest food security is attained in Ireland with a score of 84.3 followed by The Netherlands with a score of 82.6, France and Germany with identical results (scores of 82.5), the United Kingdom with a score of 81.9 and then Sweden with a score of 81.3. The lowest overall score was noted in Greece with a result of 71.5 .

Table 4. The Overall Score, Affordability, Availability, Quality and Safety of the Six Selected States from EU-13 according to the Global Food Security Index in 2016

\begin{tabular}{l|cccc}
\hline \multicolumn{1}{c|}{ Country } & Overall score & Affordability & Availability & $\begin{array}{c}\text { Quality and } \\
\text { Safety }\end{array}$ \\
\hline Bulgaria & 60,6 & 69,6 & 52,9 & 59,4 \\
Czech Republic & 73,9 & 77,5 & 70,0 & 75,9 \\
Hungary & 69,3 & 75,6 & 61,8 & 73,8 \\
Poland & 72,4 & 75,6 & 68,7 & 74,9 \\
Romania & 65,5 & 66,9 & 60,9 & 74,4 \\
Slovak Republic & 67,7 & 73,5 & 62,6 & 67,2 \\
\hline
\end{tabular}

Source: Authors' own elaboration on the basis of Global Food Security Index.

With regard to the overall score of the Food Security Index, as well as the Affordability, Availability and Quality with Safety, the most pronounced results were achieved in 2016 by the Czech Republic (score - 73.9), followed by Poland (score 72.4), then Hungary (score 69.3), Slovakia (score 67.7), Romania (score 65.5) and ending with Bulgaria (score 60.6). The overall score on the Food Security Index in six selected states from the EU-13 is lower in comparison to the EU-15 states. Furthermore, we can claim that these states are not sufficiently utilizing their comparative advantages stemming from their rich natural resources, human capital and from their good geopolitical location. 


\section{Conclusion}

The objective of this paper was to evaluate upon the basis of the Global Food Security Index, the overall food security situation in the European Union states. The countries are divided into two groups. The first is composed of fourteen selected states from EU -15 and the second consists of six selected states from the EU-13. In addition to the Food Security Index, also the Food Affordability, Food Availability, and Food Quality and Safety is analyzed.

Europe is a continent that is strong in food security, especially in quality and safety. This is confirmed also by the above analysis. The European countries are performing very well with regard to the Global Food Security Index, when from the 18 states included into our research the weakest are listed among the 50 best performing in the list out of 113 states. Therefore, Food Security as such is not a challenge for the European Union states. However, there are some critical areas which have to be carefully evaluated by concerned states with approval of follow-up steps. From Europe with regard to the Global Food Security Indicator, the best performing states are Ireland, The Netherlands and France. With regard to six states of the EU-13, the most impressive results were achieved by the Czech Republic (25), Poland (29) and Hungary (34). In general, we can state that the overall food security and safety situation is reasonably better in the EU-15 countries than in EU-13, despite the fact that the EU-13 states have a good potential for production of high quality food commodities. Slovakia is in last position in global ranking from the V4 countries, but in the $4^{\text {th }}$ place from the 6 selected states of EU-13. Behind it is Romania and Bulgaria. The most critical results were achieved by Bulgaria. Despite the very positive outcomes of the conducted research, knowing that EU-15's results are more superficial, while the food security performance in EU-13 is less convincing, but still very good, the EU leaders, and the establishments of the individual states must to take into consideration that there is still room for improvement of food quality (Slovakia, Bulgaria, Romania), as well for the improvement of food availability (Czech Republic, Bulgaria, Hungary, Slovakia, Italy, Romania and Greece).

\section{References}

Chavas, J.P. (2017). On food security and the economic valuation of food. Food Policy, 69, 58-67.

FAO. (2002). The State of Food Insecurity in the World. 2001. Rome.

FAO. (2014). Understanding hunger and malnutrition. Accessed from: http://www.fao.org/about/meetings/icn2/en.

FAO. (2015). The State of Food Insecurity in the World. 2014. Rome.

FAO. (2017a). World's future food security "in jeopardy" due to multiple challenges, report warns. Accessed from: http://www.fao.org/news/story/en/item/471169/icode/.

FAO. (2017b). The future of food and agriculture. Trends and challenges.

Fogel, R.W. (2011). The Escape From Hunger and Premature Death, 1700-2100: Europe, America, and the Third World. Cambridge University Press, Cambridge.

Global Food Security Index Report. Accessed from: http://foodsecurityindex.eiu.com/Home/Methodology.

Godfray, H.Ch.J., Beddington, J.R., Crute, I.R., Haddad, L., Lawrence, D., Muir, J.F., Pretty, J., Robinson, S., Thomas, S.M., Toulmin, C. (2010). Food security: the challenge of feeding 9 billion people. Science, 328(5967), 812-818

Kadlečíková, M., Filo, M. (2011). Food security in Central Asia and Eastern Europe and possible solutions for hunger and malnutrition in this region. Acta oeconomica et informatica, 14(1).

Priefer, C., Jörissen, J., Bräutigam, R. K. (2016). Food waste prevention in Europe - A cause-driven approach to identify the most relevant leverage points for action. Resources, Conservation and Recycling, 109, 155-165.

United Nations System: Standing Committee on Nutrition. 6th report on the world nutrition situation. Progress in nutrition. Accessed from: http://www.fao.org/3/a-as211e.pdf. 